\title{
Assessment of Undiscovered Oil and Gas Resources of the Upper Cretaceous Austin Chalk and Tokio and Eutaw Formations, Gulf Coast, 2010
}

\begin{abstract}
Using a geology-based assessment methodology, the U.S. Geological Survey estimated means of 957 million barrels of undiscovered oil, 3.6 trillion cubic feet of undiscovered natural gas, and 363 million barrels of undiscovered natural gas liquids in the Austin Chalk and Tokio and Eutaw Formations in onshore lands and State waters of the Gulf Coast.
\end{abstract}

\section{Introduction}

The U.S. Geological Survey (USGS) recently completed a geology-based assessment of the undiscovered, technically recoverable oil and gas resources in the Austin Chalk and Tokio and Eutaw Formations of the U.S. Gulf Coast region, which includes parts of Texas, Louisiana, Arkansas, Mississippi, Alabama, and Florida (fig. 1). The assessment was based on the geologic elements and petroleum processes used to define a total petroleum system (TPS), which includes petroleum source rocks (source-rock maturation and petroleum generation and migration), reservoir and seal rocks (sequence stratigraphy and petrophysical properties), and petroleum traps (trap formation, timing, and seals). Using this petroleum-system framework, the USGS defined four assessment units (AUs): (1) the AustinTokio-Eutaw Updip Oil and Gas AU, (2) the Austin-Eutaw Middip Oil and Gas AU, (3) the Austin Downdip Gas AU, and (4) the Austin Pearsall-Giddings Area Oil AU.

\section{Geologic Summary}

The Upper Cretaceous Austin Chalk is a low to moderate primary porosity and low primary permeability reservoir that relies on interconnected fracture networks for production of continuous-type accumulations; it also contains conventional-type accumulations. When assessing undiscovered accumulations, it is critical to infer the locations of: (1) conventional traps, such as faults and salt structures, and, (2) structures that are associated with fractures, such as anticlines and the Lower Cretaceous shelf edge. The Upper Cretaceous Tokio and Eutaw Formations have higher permeabilities and porosities than the Austin Chalk, do not require fracture networks for production, and contain conventional-type accumulations. Trap type influences accumulation size in conventional reservoirs, where small traps, such as fault segments, are associated with small accumulations. In addition, conventional-type accumulations tend to have well-defined boundaries and hydrocarbon-water contacts. In low-permeability continuous reservoirs, large-scale structures, such as broad anticlines and fracture networks, influence the distribution of accumulations that have diffuse boundaries and lack obvious traps and seals. The underlying Upper Cretaceous Eagle Ford Shale is the principal source rock for Austin Chalk hydrocarbons and may partially source oil and gas in Tokio and Eutaw reservoirs; it is included in the Upper Jurassic-Cretaceous-Tertiary Composite Total Petroleum System. Source rock quality of the Eagle Ford is inconsistent throughout the region, and some reservoirs in the Tokio and Eutaw may contain Jurassic-sourced hydrocarbons.
Figure 1. Map of the Gulf Coast region showing part of the Upper JurassicCretaceous-Tertiary Composite Total Petroleum System (TPS) (blue line), assessment unit (AU) boundaries (black lines), and the Lower Cretaceous shelf edge (red line). Lower Cretaceous shelf edge after Martin (1980) and Ewing and Lopez (1991).

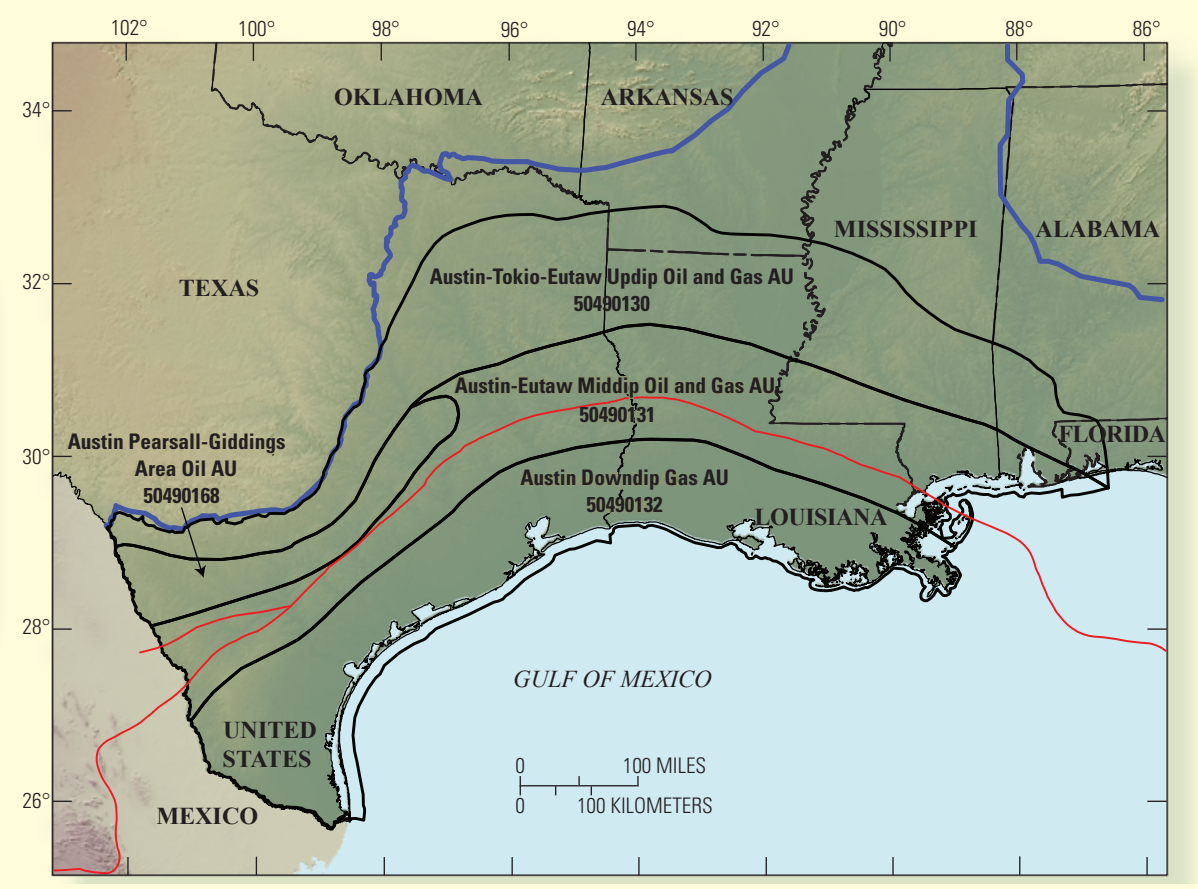


Table 1. Austin Chalk assessment results.

[MMBO, million barrels of oil. BCFG, billion cubic feet of gas. MMBNGL, million barrels of natural gas liquids. Results shown are fully risked estimates. For gas accumulations, all liquids are included as NGL (natural gas liquids). F95 represents a 95 percent chance of at least the amount tabulated; other fractiles are defined similarly. Fractiles are additive under the assumption of perfect positive correlation. TPS, total petroleum system; AU, assessment unit. Gray shading indicates not applicable]

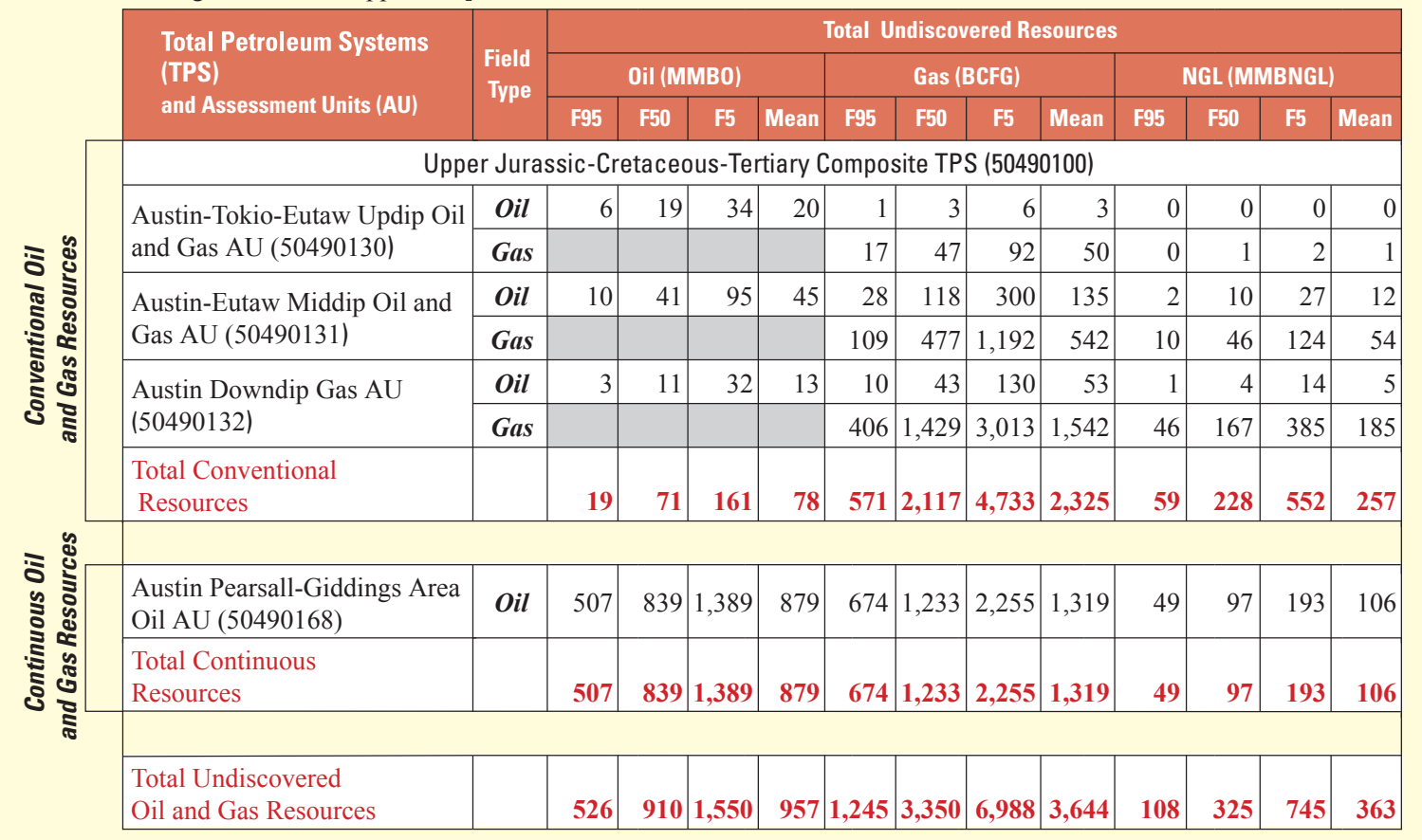

\section{Resource Summary}

The USGS assessed undiscovered, technically recoverable oil and gas resources in four assessment units (table 1). For conventional resources, the Austin-Tokio-Eutaw Updip Oil and Gas AU was assessed to contain a mean of 20 million barrels of oil (MMBO), 53 billion cubic feet of gas (BCFG), and about 1 million barrels of natural gas liquids (MMBNGL). The Austin-Eutaw Middip Oil and Gas AU was assessed to contain a total mean of $45 \mathrm{MMBO}, 677 \mathrm{BCFG}$, and 66 MMBNGL. The Austin Downdip Gas AU was assessed to contain a total mean of 13 MMBO, 1.6 trillion cubic feet of gas (TCFG), and 190 MMBNGL. The Austin Chalk and Tokio and Eutaw Formations conventional resource mean totals are: $78 \mathrm{MMBO}, 2.3$ TCFG, and 257 MMBNGL. For continuous resources, the USGS estimated a total mean of $879 \mathrm{MMBO}, 1.3 \mathrm{TCFG}$, and 106 MMBNGL for the Austin Pearsall-Giddings Area Oil AU. The assessment was based on 2008 IHS well and production data (IHS Energy Group, 2009a, 2009b) and 2006 Nehring field data (Nehring Associates, 2007).

\section{For Further Information}

Supporting geologic studies and the methodology used in the 2010 Jurassic and Cretaceous Gulf Coast Assessment are in progress. Assessment results are available at the USGS Central Energy Resources Science Center website: http://energy.cr.usgs.gov/oilgas/noga

\section{References}

Ewing, T.E., and Lopez, R.F., 1991, Principal structural features, in Salvador, A., ed., The Gulf of Mexico Basin: The Geological Society of America, The Geology of North America, v. J, plate 2.

IHS Energy Group, 2009a, PI/Dwights PLUS U.S. production data: Englewood, Colo., database available from IHS Energy Group.

IHS Energy Group, 2009b, PI/Dwights PLUS U.S. well data: Englewood Colo., database available from IHS Energy Group.

Martin, R.G., 1980, Distribution of salt structures, Gulf of Mexico: U.S. Geological Survey Miscellaneous Field Studies, Map MF-1213, scale 1:2,500,000.

Nehring Associates, 2007, The significant oil and gas fields of the United States: Colorado Springs, Colo., database available from Nehring Associates, Inc.

\section{Assessment Team}

Gulf Coast Assessment Team: Krystal Pearson (kpearson@usgs.gov), Russell F. Dubiel, Ofori N. Pearson, and Janet K. Pitman.

Review Committee: Ronald R. Charpentier, Troy A. Cook, Timothy R. Klett, Richard M. Pollastro, and Christopher J. Schenk. 